\title{
EFFECTIVENESS OF IMMOBILIZED PROBIOTICS FOR COMPLEX THERAPY OF NOVEL CORONAVIRUS INFECTION COVID-19 IN HOSPITAL SETTINGS
}

\author{
Bomshteyn NG, Bolotov YuV, Kim IA 凶, Trukhin DV
}

Scientific and Clinical Center of Otorhinolaryngology of the Federal Medico-Biological Agency of the Russian Federation, Moscow, Russia

\begin{abstract}
Taking into account the gut-lung microbiota axis, the new probiotic treatment methods for COVID-19 are currently being discussed. There are effective medicinal preparations of domestic manufacture in the Russian Federation, the immobilized probiotics. The study was aimed to determine the effectiveness of the mixed immobilized probiotic containing the immobilized B. bifidum and lactobacilli L. plantarum (100 million CFU per dose) or the simple immobilized probiotic containing the immobilized B. bifidum (500 million CFU per dose) in the complex therapy of patients with COVID-19. During the open-label, prospective, observational study 70 patients with confirmed diagnosis of COVID-19 received complex treatment which included the immobilized probiotics. All patients were discharged from the hospital with imporoved health status, as well as with improved instrumental and laboratory indicators: body temperature returned to normal in all patients; shortness of breath, cough, feeling of chest tightening, myalgia and headache disappeared; the patients regained sense of smell and taste; the weakness decreased or disappeared (pathognomic symptom for COVID-19). The dynamics of clinical, laboratory and instrumental indicators reflecting the course of the novel coronavirus infection demonstrates the effectiveness of the used complex therapy. The immobilized probiotics may be recommended for the complex treatment of patients with COVID-19,
\end{abstract}

Keywords: coronavirus infection, COVID-19, immobilized probiotics, bifidobacterium, lactobacillus

Author contribution: Bomshteyn NG, Bolotov YuV — study concept and design, data acquisition and processing, manuscript writing; Kim IA, Trukhin DV — study management, manuscript editing

Compliance with ethical standards: the study was approved by the Ethics Committee of the Scientific and Clinical Center of Otorhinolaryngology of the Federal Medico-Biological Agency of the Russian Federation (protocol № 02/20 dated April 13, 2020). All patients submitted the informed consent to participation in the study.

$\bowtie$ Correspondence should be addressed: Irina A. Kim

Volokolamskoe shosse, 30, str. 2, Moscow, 123182; irinakim_s@mail.ru

Received: 08.12.2020 Accepted: 12.12.2020 Published online: 14.12.2020

DOI: $10.47183 /$ mes.2020.021

\section{ЭФФЕКТИВНОСТЬ СОРБИРОВАННЫХ ПРОБИОТИКОВ В КОМПЛЕКСНОМ ЛЕЧЕНИИ НОВОЙ КОРОНАВИРУСНОЙ ИНФЕКЦИИ COVID-19 В УСЛОВИЯХ СТАЦИОНАРА}

\author{
Н. Г. Бомштейн, Ю. В. Болотов, И. А. Ким
}

Национальный медицинский исследовательский центр оториноларингологии Федерального медико-биологического агентства, Москва, Россия

\begin{abstract}
С учетом оси «кишечник-легкие-микробиота» в настоящее время обсуждают потенциально новые методы лечения инфекции COVID-19 с применением пробиотиков. В Российской Федерации существуют эффективные отечественные препараты - сорбированные пробиотики. Целью исследования было определить эффективность включения в комплексную терапию больных COVID-19 поликомпонентного сорбированного пробиотика, содержащего сорбированные B. bifidum и лактобактерии L. plantarum (100 млн KOE в пакете), или монокомпонентного сорбированного пробиотика, содержащего сорбированные B. bifidum (500 млн КОЕ в капсуле). В открытом проспективном наблюдательном исследовании 70 пациентам с подтвержденным диагнозом COVID-19 проводили комплексное лечение с включением сорбированных пробиотиков. Все пациенты выписаны из стационарас улучшением состояния, а также инструментальных и лабораторных показателей: у всех пациентов нормализовалась температура, исчезли одышка, кашель, ощущение заложенности в грудной клетке, миалгия, головная боль, восстановились обоняние и вкусовые ощущения, уменьшилась или исчезла слабость (характерный симптом COVID-19). Динамика клинических, лабораторных и инструментальных показателей, отражающих течение новой коронавирусной инфекции, указывает на эффективность проводимой комплексной терапии. Сорбированные пробиотики могут быть рекомендованы к применению в комплексном лечении пациентов с COVID-19.
\end{abstract}

Ключевые слова: коронавирусная инфекция, COVID-19, сорбированные пробиотики, бифидобактерии, лактобактерии

Вклад авторов: Н. Г. Бомштейн, Ю. В. Болотов - концепция и дизайн исследования, сбор и обработка материала, написание статьи; И. А. Ким, Д. В. Трухин - участие в организации работы, редактирование статьи.

Соблюдение этических стандартов: исследование одобрено этическим комитетом НМИЦО ФМБА России (протокол № 02/20 от 13 апреля 2020 г.) Все участники исследования подписали добровольное информированное согласие на участие в исследовании.

$凶$ Для корреспонденции: Ирина Анатольевна Ким Волоколамское шоссе, д. 30, корп. 2, г. Москва, 123182; irinakim_s@mail.ru

Статья получена: 08.12.2020 Статья принята к печати: 12.12 .2020 Опубликована онлайн: 14.12.2020

DOI: $10.47183 /$ mes.2020.021

The World Health Organization (WHO) on February 11, 2020 gave the disease caused by the novel coronavirus the name COVID-19 (Coronavirus Disease 2019). The emergence of COVID-19 set the healthcare specialists the task of rapid diagnosis and medical care provision. Under existing conditions of the fast spread of infection and limited evidence of the COVID-19 treatment, the $\mathrm{WHO}$ recommendations allow one to prescribe drugs off-label in accordance with the ethical standards [1].

Taking into account the gut-lung microbiota axis, which is responsible for maintaining homeostasis, the new probiotic treatment methods for COVID-19 are currently being discussed $[2,3]$. Gut microbiota contributes to the course of COVID-19 due to its relationship with immune system and lungs. Interaction between gut and lungs may affect the severity of COVID-19 [4].

There are effective medicinal preparations of domestic manufacture in the Russian Federation, probiotics, which are considered a distinct group of immobilized probiotics by the State Pharmacopoeia of the Russian Federation. Unlike other probiotics, the immobilized probiotics contain microcolonies 
of bifidobacteria on the activated carbon particles, which enable their targeted delivery to parietal biotopes of intestines, therefore increasing the effectiveness of the disease treatment and prevention [5].

The immobilized probiotics are classified into simple and mixed probiotics. There are interchangeable dosage forms of the medications (oral powder and capsules).

The simple probiotic (SIP) contains at least 500 million colony forming units (CFU) of bifidobacteria Bifidobactrium bifidum immobilized on the activated carbon particles per capsule, along with excipient (lactose monohydrate up to $0.20 \mathrm{~g}$ ). It exhibits anti-infective, antitoxic, antioxidant and antidiarrheal effect. According to the product instruction, SIPs are used as part of complex therapy of acute respiratory viral infections and flu, in patients with secondary immune deficiencies, severe infectious inflammatory and purulent septic diseases; for treatment of diarrhea of different etiology; in patients with dysbioses of different etiology, including those resulting from the use of antibiotics.

The assessment of the master seed sensitivity showed that the contained in the SIP B. bifidum 1 strain is sensitive to azithromycin [6], which should be considered when prescribing SIP together with azithromycin. In such a situation the daily dose of the immobilized probiotic should be increased.

The sachet of mixed probiotic (MIP) contains Bifidobacterium bifidum 1 immobilized on the activated carbon particles, and Lactobacillus plantarum 8P-A3 (at least 500 million CFU of each strain), together with lactose monohydrate (up to $0.85 \mathrm{~g}$ ).

According to the product instruction, MIPs are used in patients with both viral and bacterial respiratory infections, for restoration of respiratory and gut ecosystems during the period of convalescence, and in patients with dysbioses of different etiology, including those resulting from the use of antibiotics.

The capacity of oral immobilized probiotics to improve the nasopharyngeal microbiota functioning has been reported [7].

The active components of immobilized probiotics are considered benign, since the $B$. bifidum bifidobacteria and L. plantarum lactobacilli are the main representatives of the normal resident human microbiota [5].

The study was aimed to determine the effectiveness of the mixed immobilized probiotic containing the immobilized B. bifidum and lactobacilli L. plantarum (100 million CFU per dose) or the simple immobilized probiotic containing the immobilized B. bifidum (500 million CFU per dose) in the complex therapy of patients with novel coronavirus infection.

\section{METHODS}

The open-label, prospective, observational study included 70 patients admitted to the Scientific and Clinical Center of Otorhinolaryngology of the Federal Medico-Biological Agency of the Russian Federation from April 25 to May 26, 2020. Inclusion criteria: confirmed diagnosis of the novel coronavirus infection COVID-19 (positive SARS-CoV-2 RNA testing results); moderate course of the disease.

All patients underwent physical examination, laboratory and instrumental testing. The course of the disease was assessed during the physical examination on daily rounds and via control of laboratory and instrumental testing results within the recommended time-frame: complete blood count (CBC), blood chemistry tests, C-reactive protein test (CRP), chest computed tomography (chest CT), pulse oximetry, thermometry. The assessment of the lung damage severity on CT was carried out in accordance with the temporary guidelines [1].

Throughout the study the patients received standard COVID-19 therapy in accordance with the temporary guidelines of the Ministry of Health of the Russian Federation (version 6) [1] which included hydroxychloroquine, azithromycin, symptomatic and supportive care (if medically necessary).

In addition 30 patients (group 1) received SIP, 2 capsules 4 times daily within 14 days after admission to hospital, and 40 patients (group 2) received MIP, 2 sachets 3 times daily since the $2^{\text {nd }}$ week of hospital stay for 10-14 days.

The effectiveness of the therapy was assessed based on the dynamics of clinical symptoms, laboratory and instrumental testing results, and the length of hospital stay.

Statistical processing of the results was carried out using the STATISTICA 9.0 software (StatSoft Inc.; USA).

Quantitative variables were presented as median (Me), lower and upper quartiles. The discrete characters were presented as event rate (number of cases proportional to the number of observations, \%).

\section{RESULTS}

The main characteristics of the patients are presented in Table 1. Since the effectiveness of probiotics is not related to gender, and due to the features of hospitalization during the pandemic, most patients who have received treatment using the discussed scheme are males (70\%).

The following symptoms were observed in patients of both groups upon admission: elevated body temperature (within the range of $37.3-38.0{ }^{\circ} \mathrm{C}$ in 60 and $80 \%$ of patients of group 1 and group 2 respectively, and above $38{ }^{\circ} \mathrm{C}$ in 40 and $20 \%$ of patients respectively), dry cough or cough with little phlegm, the feeling of chest tightening, shortness of breath, weakness, myalgia, headache. Rhinitis and the loss of smell and taste were observed in 40-60\% of patients in group 1, and in 15-20\% of patients in group 2. No nausea, vomiting or diarrhea were detected in any of the patients.

On admission based on the empirical indicators of the visual scale (the average amount of lung tissue thickening, bilateral) most patients of group 1 (60\%) were diagnosed with moderate lung lesion on CT (CT2), and $40 \%$ of the patients were diagnosed with mild lung lesion (CT1). Among patients of group 2, moderate lung lesion (CT2) was diagnosed in 37.5\%, and mild lung lesion (CT1) was diagnosed in $62.5 \%$. It should be noted that the differences in the lung damage rate in patients of studied groups were not significant $\left(\chi^{2}=2.64, p=0.104\right.$, the critical value $\chi^{2}=3.84$ at $p=0.05$ )

The oxygen saturation values obtained by pulse oximetry $\left(\mathrm{SpO}_{2}\right)$ in patients of group 1 were $97-96 \%$ (all patients), in patients of group 2 they were $97 \%$ or less (60\% of patients), and $98 \%$ (40\% of patients).

The CRP level was within the reference range in $20 \%$ of patients of group 1, and $40 \%$ of patients of group 2, exceeded the reference value by $1.8-14.8$ times in $80 \%$ of patients of group 1, and by 2.3-19.7 times in 60\% of patients of group 2 .

The complete blood count (CBC) revealed the decrease in the number of leukocytes $\left(3.12-3.60 \times 10^{\%} / L\right)$ in $60 \%$ of patients of group 1. Alterations in white blood cell count were detected in $10 \%$ of patients. The other parameters' values were within the reference ranges in all patients. Complete blood count in patients of group 2 revealed alterations in the percentage of certain white blood cell types and the total white blood cell count (slight decrease) in $15 \%$ of patients. In the rest of the patients (75\%), all indicators were within normal range.

The blood chemistry test values (urea, creatinine, bilirubin, glucose, albumin, electrolytes) in all patients of group 1 were within the reference range. In $10 \%$ of patients the elevated values of ALT and AST were observed, and in other $90 \%$ 
Table 1. Characteristics of patients included in the study

\begin{tabular}{|c|c|c|c|}
\hline Parameter & & Group $1(n=30)$ & Group $2(n=40)$ \\
\hline Average age, years (Me [lower quartile; upper quartile]) & & $51[45 ; 64]$ & $47[32 ; 53]$ \\
\hline \multicolumn{4}{|l|}{ Principal diagnosis } \\
\hline Novel coronavirus infection COVID-19 (confirmed), moderate course, U07.1, abs. (\%) & & $30(100)$ & $40(100)$ \\
\hline \multicolumn{4}{|l|}{ Complications } \\
\hline Community-acquired pneumonia, bilateral polysegmental, J18.9, abs. (\%) & & $30(100)$ & $40(100)$ \\
\hline \multicolumn{4}{|l|}{ Comorbidities, abs. (\%) } \\
\hline Hypertensive heart disease & & $12(40)$ & $11(27.5)$ \\
\hline Type 2 diabetes mellitus & & $2(6.7)$ & $4(10)$ \\
\hline History of the gastrointestinal tract disorders & & $9(30)$ & $8(20)$ \\
\hline History of chronic bronchitis & & $3(10)$ & $5(12.5)$ \\
\hline Bronchial asthma & & $1(3,3)$ & - \\
\hline Chronic sinusitis & & - & $2(5)$ \\
\hline \multicolumn{4}{|l|}{ Clinical parameters upon admission, abs. (\%) } \\
\hline Elevated body temperature & & $30(100)$ & $40(100)$ \\
\hline Feeling of chest tightening & & $30(100)$ & $40(100)$ \\
\hline Shortness of breath & & $30(100)$ & $40(100)$ \\
\hline Fatigue, weakness & & $30(100)$ & $40(100)$ \\
\hline Myalgia & & $30(100)$ & $40(100)$ \\
\hline Headache & & $30(100)$ & $40(100)$ \\
\hline Rhinitis & & $9(30)$ & $6(15)$ \\
\hline Loss of smell and taste & & $10(33.3)$ & $8(20)$ \\
\hline \multicolumn{4}{|l|}{ Pulmonary lesions severity on CT, abs. (\%) } \\
\hline & CT 1 & $12(40)$ & $25(62.5)$ \\
\hline & CT 2 & $18(60)$ & $15(37.5)$ \\
\hline
\end{tabular}

of patients these values were within the reference range. The blood chemistry test values in patients of group 2 (urea, creatinine, ALT, AST, bilirubin, glucose, albumin, electrolytes) were within the reference range in $85 \%$ of patients, and $15 \%$ of patients had elevated transaminase level. In patients with diabetes mellitus of both groups, the glucose level was within the range typical for compensated state.

The clinical parameters dynamics along with the length of hospital stay for group 1, which received SIP since the day of admission to hospital, is presented in Table 2.

In most patients, the body temperature decrease was observed on day 10 of hospital stay, body temperature dropped to normal on days $14-15$, and the cough and the feeling of chest tightening decreased and disappeared within the same period. In most patients, the shortness of breath disappeared within 6 days of treatment, and on day 9 no shortness of breath was observed in all patients. Myalgia and headache decreased and disappeared within the same period. In patients who experienced the loss of smell and taste, the sense of smell and taste recovered on days 10-14, and rhinitis disappeared during the same period. On the day of discharge the weakness disappeared in $70 \%$ of patients, and decreased in $30 \%$ of patients.

Thus, under complex treatment, on the day of discharge all patients had no elevated body temperature, shortness of breath, cough, feeling of chest tightening, myalgia, headache or rhinitis. The sense of smell and taste recovered, and the weakness disappeared in most patients.

All patients had regular and well-formed stool during the whole observation period.

On the day of discharge the mild lung lesion on CT (CT1) indicating the clinical improvement was diagnosed in all patients. The oxygen saturation and CRP level values were back to normal.

The dynamics of complete blood count showed the increase in the number of leukocytes in all patients, who had the decreased number of leukocytes upon admission. On the day of discharge only one patient had low number of leukocytes compared to reference value, however, that value was close to the lower threshold of reference range.

On the day of discharge from hospital the blood chemistry test values were within the reference range in all patients.

Table 2. Clinical parameters dynamics and the length of hospital stay for the group of patients who received SIP

\begin{tabular}{|l|c|c|}
\hline \multicolumn{1}{|c|}{ Parameter } & Day of improvement ${ }^{*}$ & Day of the symptom disappearance * $^{*}$ \\
\hline Elevated body temperature & $10[9 ; 11]$ & $15[14 ; 16]$ \\
\hline Shortness of breath & $4[4 ; 5]$ & $6[5 ; 7]$ \\
\hline Feeling of chest tightening & $10[9 ; 11]$ & $15[14 ; 16]$ \\
\hline Cough & $10[9 ; 11]$ & $15[14 ; 16]$ \\
\hline Myalgia & $4[3 ; 5]$ & $6[5 ; 7]$ \\
\hline Headache & $4[3 ; 5]$ & $6[5 ; 7]$ \\
\hline Length of hospital stay $\left(\right.$ days) $^{*}$ & \multicolumn{2}{|c|}{$18[17 ; 19]$} \\
\hline
\end{tabular}

Note: * — median [lower quartile; upper quartile]. 
Table 3. Clinical parameters dynamics and the length of hospital stay for the group of patients who received MIP

\begin{tabular}{|l|c|c|}
\hline \multicolumn{1}{|c|}{ Parameter } & $\begin{array}{c}\text { Number of patients exhibiting the symptom when } \\
\text { starting MIP, abs. (\%) }\end{array}$ & $\begin{array}{c}\text { Day of the symptom disappearance after starting } \\
\text { MIP }\end{array}$ \\
\hline Elevated body temperature & $34(85)$ & $4[3 ; 5]$ \\
\hline Shortness of breath & $34(85)$ & $4[3 ; 6]$ \\
\hline Feeling of chest tightening & $37(92.5)$ & $5[4 ; 6]$ \\
\hline Cough & $37(92.5)$ & $5[4 ; 6]$ \\
\hline Myalgia & $20(50)$ & $4[3 ; 5]$ \\
\hline Headache & $20(50)$ & $4[3 ; 5]$ \\
\hline Length of hospital stay (days) & & \\
\hline
\end{tabular}

Note: * median [lower quartile; upper quartile].

The clinical parameters dynamics along with the length of hospital stay for group 2, which received MIP since the $2^{\text {nd }}$ week of hospital stay, is presented in Table 3.

The body temperature dropped to normal on days 3-5 of exposure to MIP in most patients, myalgia and headache disappeared within the same period. Shortness of breath disappeared, feeling of chest tightening and cough within 6 days of treatment. In patients who experienced the loss of smell and taste, the sense of smell and taste recovered on days 4-5 of treatment with MIP, rhinitis disappeared during the same period. Weakness disappeared on days 5-14 of exposure to MIP, more often on days 7-8. On the day of discharge no weakness was observed in all patients.

Thus, under complex treatment, on the day of discharge all patients had no elevated body temperature, shortness of breath, cough, feeling of chest tightening, myalgia, headache, weakness and rhinitis. The sense of smell and taste recovered.

All patients had regular and well-formed stool during the whole observation period.

The dynamic changes of chest CT based on the empirical visual assessment data are presented in Table 4.

Prior to starting MIP, the changes of CT findings were observed in all patients: no clinical worsening compared to the CT scan results obtained on admission was detected in $25 \%$ of patients, and $75 \%$ of patients showed signs of clinical improvement. Under complex treatment with the use of MIP, on the day of discharge the mild lung lesion on CT was diagnosed in all patients, indicating the clinical improvement. The oxygen saturation and CRP level values were back to normal.

When starting MIP, only one patient showed slight decrease in the number of leukocytes, the other patients' values were within the reference range. On the day of discharge the complete blood count values were within the reference range in all patients. The blood chemistry test values also corresponded to reference values, except for patients with diabetes mellitus, whose glucose level was elevated, but was within the range typical for compensated state.

The use of immobilized probiotics revealed no side effects, adverse events or adverse reactions.

\section{DISCUSSION}

In the context of sharp rise in the incidence of the novel coronavirus infection COVID-19 resulting in severe patients' condition and sometimes being lethal, and the lack of precise treatment schemes, there was an urgent need for medical care improvement. Therefore, the use of the medicinal preparations of domestic manufacture, the immobilized probiotics with high safety profile and proven effectiveness regarding the acute respiratory illnesses, for complex treatment seemed natural enough. Moreover, the capability of immobilized probiotics to prevent and neutralize the adverse effects of antibacterial therapy is well known [5, 7]. To avoid the excess load and the divergent effect on the gut microbiota and human body, the possibility to use the simple probiotic containing the microcolonies of Bifidobacterim bifidum in terms of effectiveness dramatically different from preparations containing single cells of bifidobacteria of this species during the acute period of the disease was considered important [5]. The treatment using the specially selected combination of Bifidobacterim bifidum microcolonies with the Lactobacillus plantarum species (MIP) was started since the $2^{\text {nd }}$ week of hospital stay $[5,7]$. During the observational study the complex treatment results were analyzed in each of two groups of patients who received SIP and MIP in accordance with different treatment schemes.

Despite the small sample size and the lack of comparison group, when analyzing the results of COVID-19 patients' complex treatment, which included SIP and MIP, the general state improvement, as well as the improvement of the laboratory and instrumental testing results stood out in all patients. Under complex treatment on the day of discharge all patients had no elevated body temperature, shortness of breath, cough, feeling of chest tightening, myalgia, and headache. The weakness, being a pathognomic symptom for COVID-19, disappeared in all patients who received MIP, and in most patients, who received SIP. All patients of the studied groups, who exhibited the smell and taste loss upon admission, regained sense of smell and taste during the $2^{\text {nd }}$ week of treatment. Even though the recovery of smell and taste is typical for the $2^{\text {nd }}-4^{\text {th }}$ week from the beginning of the disease, it never occurs in all patients. Therefore the fact of smell and taste recovery under treatment with immobilized probiotics merits consideration and may be subject to further research.

The patients received essential therapy which adversely affected the gut microbiota, however, none of them complained of flatulence, abdominal pain, and diarrhea. All patients had regular, well-formed stool during the whole observation period, which could be due to positive effect of MIP and SIP on the gut microbiota and better tolerability of essential therapy.

Table 4. Dynamic changes of chest CT based on the empirical visual assessment data

\begin{tabular}{|c|c|c|c|c|c|}
\hline \multicolumn{2}{|c|}{ Upon admission } & During treatment (days 2-3 of taking MIP) & \multicolumn{2}{c|}{ On the day of discharge } \\
\hline CT results & Number of patients, abs. (\%) & CT results & Number of patients, abs. (\%) & CT results & Number of patients, abs. (\%) \\
\hline CT 2 & $15(37.5)$ & CT 2 & $12(30)$ & CT 2 & CT 1 \\
\hline CT 1 & $25(62.5)$ & CT 1 & $28(70)$ & $40(100)$ \\
\hline
\end{tabular}




\section{CONCLUSION}

Upon the novel coronavirus infection COVID-19 complex treatment with the use of medication containing immobilized B. bifidum 1 and L. plantarum 8P-A3 or immobilized B. bifidum 1,

\section{References}

1. Vremennye metodicheskie rekomendacii «Profilaktika, diagnostika i lechenie novoj koronavirusnoj infekcii (COVID-19)». Ministerstvo zdravoohranenija Rossijskoj Federacii. Versija 6, 2020; 164 s. Russian.

2. Conte L, Maurizio Toraldo D. Targeting the gut-lung microbiota axis by means of a high-fibre diet and probiotics may have antiinflammatory effects in COVID-19 infection. Ther Adv Respir Dis. 2020; 14: 1-5. DOI: 10.1177/1753466620937170 39.

3. Gao QY, Chen YX, Fang JY. 2019 novel coronavirus infection and gastrointestinal tract. J Dig Dis. 2020; 21: 125-26. DOl: 10.1111/1751-2980.12851. 40.

4. Aktas B. Aslim B. Gut-lung axis and dysbiosis in COVID-19. Turk all patients demonstrated the improvement of clinical, laboratory and instrumental indicators reflecting the course of the disease, which indicated the effectiveness of the therapy. The immobilized probiotics may be recommended for the complex treatment of patients with COVID-19.

\section{Литература}

1. Временные методические рекомендации «Профилактика, диагностика и лечение новой коронавирусной инфекции (COVID-19)». Министерство здравоохранения Российской Федерации. Версия 6. 2020; 164 с.

2. Conte L, Maurizio Toraldo D. Targeting the gut-lung microbiota axis by means of a high-fibre diet and probiotics may have antiinflammatory effects in COVID-19 infection. Ther Adv Respir Dis. 2020: 14: 1-5. DOI: 10.1177/1753466620937170 39.

3. Gao QY, Chen YX, Fang JY. 2019 novel coronavirus infection and gastrointestinal tract. J Dig Dis. 2020; 21: 125-26. DOl: 10.1111/1751-2980.12851. 40.

4. Aktas B. Aslim B. Gut-lung axis and dysbiosis in COVID-19. Turk

J Biol. 2020 Jun 21; 44 (3): 265-72. DOI: 10.3906/biy-2005-102.

5. Кареткин Б. А., Дорошенко Е. О., Ланских А. Г., Терешкова Е. А. Сорбированные пробиотики. Механизм действия. М.: ТД ДеЛи, 2020; 36 с.

6. Алешкин В. А., Афранасьев С. С., Караулов А.В. Микробиоценозы и здоровье человека. Москва: Династия, 2015; 548 с.

7. Феклисова Л. В., Ющук Н. Д., Аликеева Г. К. Результаты многоцентровых клинико-лабораторных исследований назначения сорбированного поликомпонентного препаратапробиотика детям и взрослым при инфекционной патологии Инфекционные болезни: новости, мнения, обучение. 2015; 1 : 66-76. 